
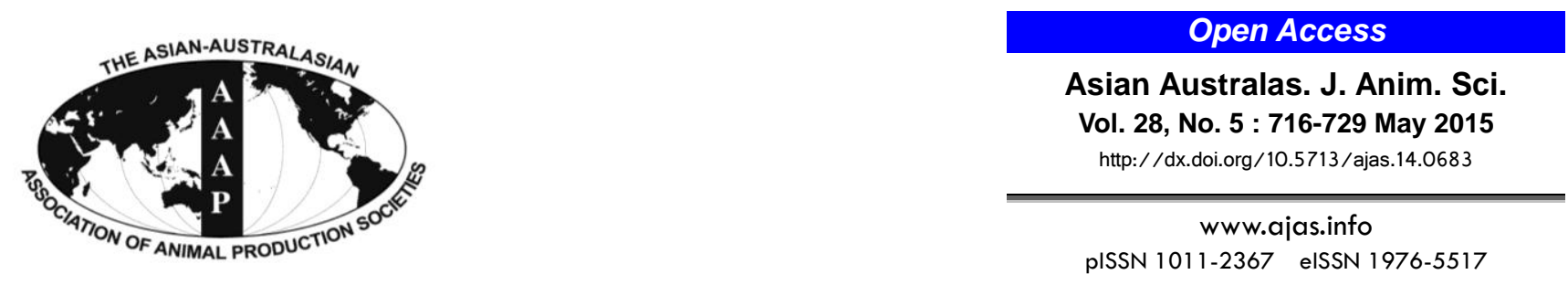

\title{
Life Cycle Assessment of Biogas Production in Small-scale Household Digesters in Vietnam
}

\author{
T. K. V. Vu, D. Q. Vu ${ }^{1,2}$, L. S. Jensen ${ }^{2}$, S. G. Sommer ${ }^{3}$, and S. Bruun ${ }^{2, *}$ \\ National Institute of Animal Sciences, Hanoi 10000, Vietnam
}

\begin{abstract}
Small-scale household digesters have been promoted across Asia as a sustainable way of handling manure. The major advantages are that they produce biogas and reduce odor. However their disadvantages include the low recycling of nutrients, because digestate is dilute and therefore difficult to transport, and the loss of biogas as a result of cracks and the intentional release of excess biogas. In this study, life cycle assessment (LCA) methodology was used to assess the environmental impacts associated with biogas digesters in Vietnam. Handling $1,000 \mathrm{~kg}$ of liquid manure and $100 \mathrm{~kg}$ of solid manure in a system with a biogas digester reduced the impact potential from $4.4 \mathrm{~kg}$ carbon dioxide $\left(\mathrm{CO}_{2}\right)$ equivalents to $3.2 \mathrm{~kg} \mathrm{CO}$ equivalents compared with traditional manure management. However, this advantage could easily be compromised if digester construction is considered in the LCA or in situations where there is an excess of biogas which is intentionally released. A sensitivity analysis showed that biogas digesters could be a means of reducing global warming if methane emissions can be kept low. In terms of eutrophication, farms with biogas digesters had 3 to 4 times greater impacts. In order to make biogas digesters sustainable, methods for recycling digestates are urgently required. (Key Words: Manure, Digestate, Methane, Global Warming, Euthrophication)
\end{abstract}

\section{INTRODUCTION}

Livestock production has increased dramatically in south-east Asia, with small-scale production units being upgraded or replaced by larger-scale production units (Costales et al., 2006). This calls for appropriate manure management strategies that have minimal impacts on the environment, facilitate the efficient recycling of plant nutrients and preferably generate "green" energy with little or no global warming potential.

\footnotetext{
* Corresponding Author: S. Bruun. Tel: +45-35333481, E-mail: sab@plen.ku.dk

${ }^{1}$ Vietnamese Academy of Agricultural Sciences, Thanh Tri, Hanoi 10000, Vietnam.

${ }^{2}$ Department of Plant and Environmental Sciences, Faculty of Science, University of Copenhagen, DK-1871 Frederiksberg C., Denmark.

3 Department of Chemical Engineering, Biotechnology and Environmental Technology, Faculty of Engineering, University of Southern Denmark, 5230 Odense, Denmark.

Submitted Sept. 4, 2014; Revised Nov. 5, 2014; Accepted Nov. 20, 2014
}

Vietnamese farms are traditionally small and run by a single family. Pig houses are cleaned by scraping away solids and hosing down liquid manure (Vu et al., 2007; Thien Thu et al., 2012). Liquids from animal houses are predominantly discharged directly into the environment, into a lagoon from where they seep into the ground or evaporate, or into fishponds. Solids are stored or composted for use on agricultural fields or gardens or in fishponds.

As an alternative to this, the anaerobic digestion of manure in small-scale biogas digesters has a number of advantages. Its major benefits are the production of biogas - a valuable fuel - and the reduction of odor and greenhouse gas emissions (Pei-dong et al., 2007; Yu et al., 2008; Rajendran et al., 2012). Biogas can be used in households for cooking, heating and lighting, and can contribute towards improving farmers' livelihoods and to reduce the use of coal, liquid petroleum gas (LPG) and wood for cooking. In addition, it reduces the biological oxygen demand of the manure and the associated propensity of the manure to consume oxygen and create anoxic conditions, and to produce methane $\left(\mathrm{CH}_{4}\right)$ and nitrous oxide 
$\left(\mathrm{N}_{2} \mathrm{O}\right)$ emissions upon discharge to the aquatic environment (Yu et al., 2008; Park and Craggs, 2013). For these reasons, anaerobic digestion units have been widely advocated and large subsidies for biogas units offered throughout Vietnam, mainly via development aid from the Netherlands, the Asian Development Bank, the World Bank and government support (Department of Livestock Production, 2010). This has increased the number of anaerobic digestion systems significantly over the past two decades (Eastern Research Group, 2010) and approximately 200,000 biogas digesters are currently in operation in Vietnam (Department of Livestock Production, 2010). There are, however, disadvantages associated with the anaerobic digestion of manure. One disadvantage is that solid manure which would normally be left in the animal house, and subsequently taken out to fields, gardens or fishponds, is washed into the biogas digester ( $\mathrm{Vu}$ et al., 2012c). In contrast, the slurry (solids, urine, washing water) fed into the digester is diluted. As a consequence of this, transportation is a barrier to recycling digestate in fields (Thien Thu et al., 2012). This means that digestate containing fiber and nutrients is not recycled, but is typically discharged into the environment. Another disadvantage is that biogas may be emitted from the system, which is a problem because the $\mathrm{CH}_{4}$ it contains is a potent greenhouse gas. The primary reasons for these emissions are cracks in the digesters and the intentional release of biogas when production exceeds demand (Bruun et al., 2014).

The problems with the biogas digesters are being exacerbated by the growing size and intensification of livestock production units. Increased input into a biogas digester designed for smaller livestock production means a decrease in retention time and inadequate utilization of $\mathrm{CH}_{4}$ potential. The increased input of manure may also mean that biogas production increases above the amount needed in the household, with excess gas being released into the environment ( $\mathrm{Vu}$ and Dinh, 2012). This could be accentuated by an increased use of commercial animal feed (Department of Livestock Production, 2013) as biogas is no longer needed for cooking traditional, fiber-rich animal feed.

The advantages associated with biogas digesters may therefore come at a price and it could be questionable whether the advantages outweigh the disadvantages with current biogas management practices.

Life cycle assessment (LCA) is a tool that can be used to compare the environmental impacts of different products throughout their entire life cycle (European Commission, 2010). The LCA has been used to compare different biogas production technologies (Rehl and Muller, 2011; Poeschl et al., 2012a). Several studies have also focused on technologies for biogas production from manure and different co-substrates for manure (Hamelin et al., 2011;
Rehl and Muller, 2011; De Vries et al., 2012; Poeschl et al., 2012a). However, very few studies have focused on the vast number of small-scale biogas digesters being deployed in developing countries. Only one single study has been identified (Chen et al., 2012) and this study largely ignores the issues of $\mathrm{CH}_{4}$ leakage and release and nutrient recycling.

The objective of this study was to use LCA methodology to assess the environmental impacts associated with standard biogas digesters in Vietnam and to compare them with the impacts associated with other standard manure management practices in order to determine whether the current employment of biogas digesters has net positive or negative environmental impacts.

\section{METHODOLOGY}

\section{Life cycle assessment approach and data sources}

In this study, LCA was used to assess the environmental impacts of pig manure management systems with and without biogas digesters throughout the entire life cycle of manure, from storage to field application. The methodology used is in accordance with the standards described in ISO standards ISO 14044 (ISO, 2006a) and ISO 14040 (ISO, 2006b).

The functional unit (FU) applied was the treatment of $100 \mathrm{~kg}$ of solid pig manure and $1,000 \mathrm{~kg}$ of liquid pig manure collected from animal houses. The ratio between solids and liquids corresponds to the actual ratio produced on small-scale pig farms ( $\mathrm{Vu}$ et al., 2012a), although it would depend very much on local conditions.

The ReCiPe 2008 impact assessment method (Goedkoop et al., 2009) was applied in this study to assess the impact in four different categories: i) global warming potential, ii) marine water eutrophication, iii) freshwater eutrophication, and iv) fossil fuel depletion. These categories cover the most important environmental emissions and energy resource issues and are important impacts of parameters for livestock manure. However, it should be noted that the spreading of pathogens and emissions of odor might also be important categories (Sandars et al., 2003). These have not been considered in this study as impact methods do not currently exist for them.

\section{Manure management systems}

Two manure management systems, one with a biogas digester and one without, are compared (Figure 1). The systems were defined to reflect current farm practices on small and medium-scale Vietnamese pig farms with and without biogas, as observed in a contemporary survey ( $\mathrm{Vu}$ et al., 2012a).

The manure management system of biogas farms is illustrated in Figure 1a. The life cycle stages for biogas farms include an anaerobic fermentation stage for biogas 


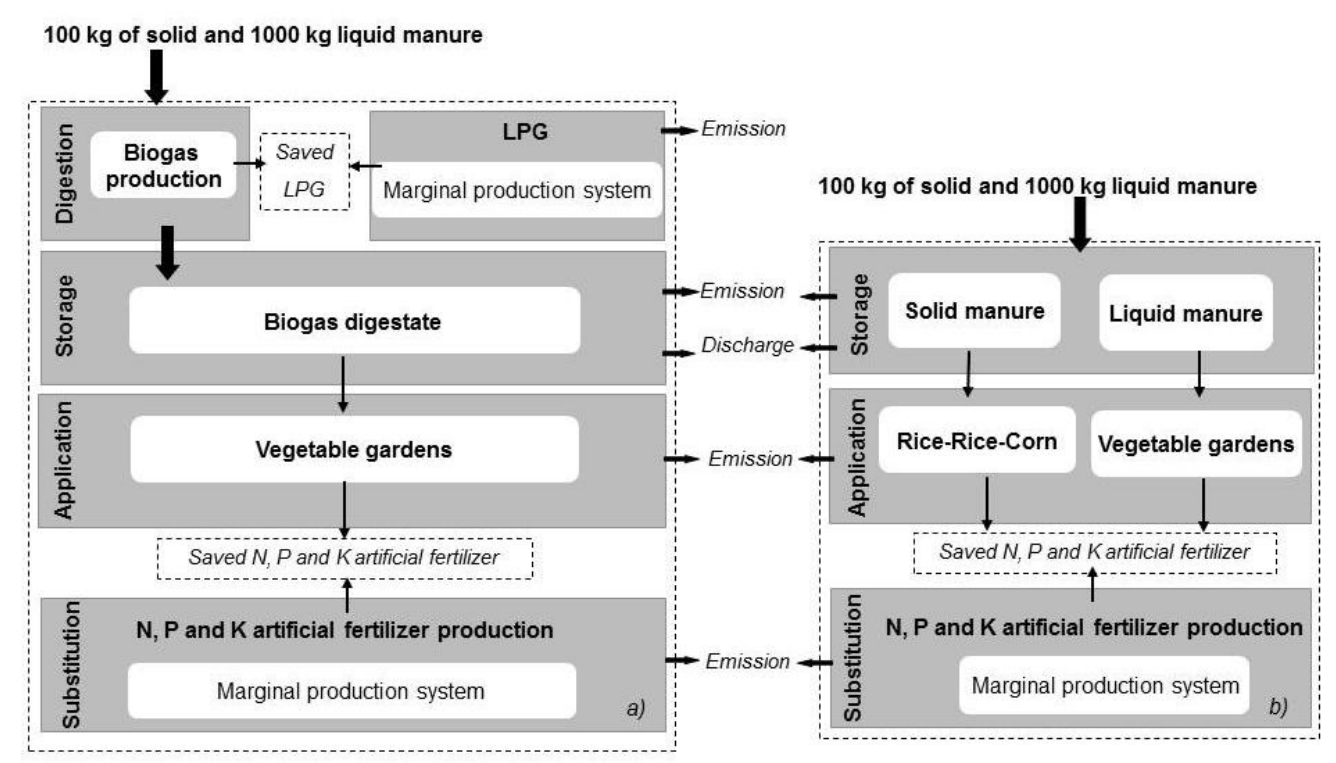

Figure 1. Pig manure management system with biogas production (left) and without biogas production (right), including substitution for mineral fertilizer and discharge into the environment.

production. After the digester, there is a stage with digestate storage. The digestate is subsequently collected for field crops, mainly for vegetable gardens, and it is assumed that the nutrients replace mineral fertilizers. Overflow from the storage tank is discharged directly into the aquatic environment. Biogas is used for household consumption, replacing LPG in this study.

The manure management system of non-biogas farms is illustrated in Figure 1b. The different stages of the life cycle are storage and application on field crops, where mineral fertilizer is replaced or substituted. The solid manure is mainly used for crops, the most common use being a ricerice-corn cropping sequence. The liquid manure is often used for vegetable gardens, but a significant fraction is also discharged either into a lagoon, where it seeps into the ground or evaporates, or directly into the aquatic environment. It is assumed that the nutrients contained in the manure applied to crops replace mineral fertilizers, thus avoiding the production and application of fertilizers.

Emissions from pig housing were not included, since it is assumed that these are similar in farms with and without biogas digesters.

In northern Vietnam, it is still common practice to use manure to fertilize aquatic plants used as fish feed in fishponds. However, as pig and fish farming are gradually developing, this practice is likely to become less common in future because consumers are increasingly avoiding fish fed with manure because of the foul aftertaste. This tendency is already being observed in southern Vietnam. Fishponds were therefore not included in this study.

\section{Assumptions used for emissions inventory}

The chemical composition of the solid and liquid fractions that constitute the functional unit was calculated from data collected in connection with the survey reported in $\mathrm{Vu}$ et al. (2012b). As the differences in manure composition between farms with and without biogas were small, an average of the composition was calculated as a mixture of the solid and liquid fractions from farms without biogas. Organic carbon was estimated by a linear relation with volatile solids (Schulte and Hopkins, 1996). The slope was found by using data reported by Vu et al. (2009). This resulted in the following relationship: Organic carbon $(\%)=$ volatile solids $(\%) \times 0.552$. The resulting composition of the manures can be found in Table 1 .

The composition of the digestate was measured, but the measurements reflect the liquid digestate in the outlet and do not include the solids that continuously sediment at the bottom of the digester during operation and that are cleaned out regularly. Instead, the composition of the digestate was

Table 1. Chemical composition pig manure as solid, liquid and slurry from animal houses in households with and without biogas $(\mathrm{n}=24)$

\begin{tabular}{lccc}
\hline Criteria & Solid & Liquids & $\begin{array}{c}\text { Slurry } \\
\text { (for biogas) }\end{array}$ \\
\hline \multirow{3}{*}{$\mathrm{g} \cdot \mathrm{kg}^{-1}$ (wet weight) } \\
Dry matter & 281 & 3.4 & 28.6 \\
Ash & 69.14 & 1.55 & 7.70 \\
Volatile solid & 212 & 1.85 & 20.9 \\
Organic C & 117 & 1.02 & 11.6 \\
Organic N & 9.91 & 0.541 & 1.39 \\
$\mathrm{NH}_{4}-\mathrm{N}$ & 0.826 & 0.128 & 0.191 \\
Total $\mathrm{N}$ & 10.7 & 0.669 & 1.584 \\
Total P & 6.20 & 0.263 & 0.802 \\
Total K & 1.92 & 0.162 & 0.322 \\
\hline
\end{tabular}


calculated by mass balances as follows: i) the ash, P, K, and $\mathrm{N}$ content of the digestate was calculated by assuming that all of these components that entered the digester also left it again; ii) ammonium in the digestate was equal to the measured ammonium concentration in the digestate leaving the storage plus the estimated emission of ammonia nitrogen during storage of the digestate; iii) total $\mathrm{N}$ in the digestate was calculated as total $\mathrm{N}$ in manure minus $\mathrm{N}$ in biogas produced; iv) organic nitrogen in the digestate was calculated as total nitrogen in the digestate minus the ammonium; v) organic $\mathrm{C}$ in the digestate was estimated as organic $\mathrm{C}$ input (organic $\mathrm{C}$ in solid and liquid manure) minus $\mathrm{C}$ in the biogas produced.

The survey reported in $\mathrm{Vu}$ et al. (2012b) indicated that the proportion of manure discharged directly or after storage was $2.5 \%$ of total solid manure and $43.7 \%$ of liquid manure. The farms with biogas discharged $62.5 \%$ of the digestate. All discharges occurred directly into the aquatic environment or via a lagoon.

On average, $1 \mathrm{~kg}$ manure with $28.5 \%$ dry matter produces 50 liters of biogas, which consists of $60 \% \mathrm{CH}_{4}$, $35 \% \mathrm{CO}_{2}$ and $5 \%$ other gases in small-scale Vietnamese manure biogas digesters (SNV-VN, 2012). Based on this observation, it was assumed that 175 liters of biogas were produced per $\mathrm{kg}$ of dry matter in the slurry, corresponding to $0.24 \mathrm{~m}^{3}$ biogas $\mathrm{kg}^{-1}$ volatile solids, with the values of dry matter and volatile solids given for slurry in Table 1.

The amount of fuel that can be substituted was calculated based on the cooking efficiencies of the different fuels, ensuring that the same amount of efficient energy was delivered from the biogas as from the alternative fuel being substituted. The efficiencies used are given in Table 2 .

During the combustion of biogas and other fuels, $\mathrm{CO}_{2}$ and other gases are emitted into the atmosphere. The $\mathrm{CO}_{2}$ emitted during the combustion of biogenic fuels such as biogas are considered $\mathrm{CO}_{2}$ neutral. In addition to the $\mathrm{CO}_{2}$, the combustion of fuels also releases small quantities of $\mathrm{CH}_{4}, \mathrm{~N}_{2} \mathrm{O}$, and $\mathrm{CO}$, all of which have climate warming potential. The emission of these gases when delivering $1 \mathrm{MJ}$ to a cooking pot is presented in Table 2 .

Besides emissions from the combustion of biogas, there are two sources of biogas losses: i) cracks in biogas digesters and tubing and ii) intentional release.

There is very little information about losses through cracks available in literature. Dhingra et al. (2011) measured insignificant losses through cracks in wellmaintained digesters. However, it is likely that most digesters are not well maintained. Thien Thu et al. (2012) and Vu et al. (2012b) observed cracks in dome digester caps and gas valves that were not airtight in Vietnam. Bruun et al. (2014) assumed that losses could be as high as $10 \%$ from small-scale biogas digesters, while Prapaspongsa et al. (2010) assumed a value of 5\% for small-scale biogas digesters in Thailand. Here a loss of $5 \%$ was also assumed.

Intentional release into the atmosphere occurs when biogas production is greater than consumption and biogas pressure builds up in the digester. In southern Vietnam, the loss of biogas due to intentional release was estimated to be up to $36 \%$ of the biogas produced (Bruun et al., 2014). In northern Vietnam, where pig farms are smaller and biogas production lower during the winter, excess biogas release is likely to be smaller than in the south. Unpublished data from the survey carried out by Thien Thu et al. (2012) has shown that of 85 households with biogas digesters, 16 had excess biogas which they could not use. Of these, eight would burn it, five would release it, and three would supply some to a neighbor and burn some. Using the data available it is estimated that the release may only account for up to $7 \%$ of the biogas produced. Adding potential losses due to intentional release and cracks, it is concluded that losses may be somewhere between $5 \%$ and $12 \%$ of biogas production.

Emissions occurring during the storage of manure and digestate include $\mathrm{NH}_{3}, \mathrm{~N}_{2} \mathrm{O}, \mathrm{CH}_{4}$, and $\mathrm{CO}_{2}$ (Table 3).

For solid manure storage, an $\mathrm{NH}_{3}$ emission factor of 0.308 of total $\mathrm{N}$ was used. This was estimated as an average of 13 studies with farmyard manure from pigs reviewed by Webb et al. (2012). As the physical and chemical characteristics of Vietnamese manure are comparable to the range of manures reviewed in the study of Webb et al. (2012) this assumption seems justified. For $\mathrm{N}_{2} \mathrm{O}$, an emission factor of 0.005 given by Eggleston et al. (2006) for unconfined solid manure piles was used. $\mathrm{A} \mathrm{CO}_{2}$ emission factor of $0.015 \mathrm{~kg} \mathrm{CO}_{2}-\mathrm{C}(\mathrm{kg} \text { dry matter })^{-1}$ was taken from $\mathrm{Vu}$ et al. (2012d). The $\mathrm{CH}_{4}$ emission factor was calculated using the formula: $\mathrm{EF}=\mathrm{B}_{\mathrm{o}} \times 0.67 \times \mathrm{MCF}$ (Eggleston et al., 2006) where EF is the emission factor $(\mathrm{kg}$ $\mathrm{CH}_{4} \mathrm{~kg}^{-1}$ volatile solid), $\mathrm{B}_{\mathrm{o}}$ is the maximum $\mathrm{CH}_{4}$ production capacity of the stored solids which is $0.29 \mathrm{~m}^{3} \mathrm{CH}_{4} \mathrm{~kg}^{-1}$ volatile solid for Asia, 0.67 is the conversion factor of $\mathrm{m}^{3}$

Table 2. Energy content of biogas, energy efficiency factor and greenhouse gas emissions during combustion of different fuels ${ }^{1}$

\begin{tabular}{|c|c|c|c|c|c|c|}
\hline & \multirow{2}{*}{$\begin{array}{c}\text { Energy content of fuel } \\
\qquad \mathrm{MJ} \cdot \mathrm{kg}^{-1}\end{array}$} & \multirow{2}{*}{$\begin{array}{l}\text { Energy efficiency factor } \\
\qquad \%\end{array}$} & \multicolumn{4}{|c|}{ Gas emission per MJ delivered energy } \\
\hline & & & $\mathrm{g} \mathrm{CO}_{2}$ & $\mathrm{mg} \mathrm{CH}_{4}$ & $\mathrm{~g} \mathrm{CO}$ & $\mathrm{mg} \mathrm{N}_{2} \mathrm{O}$ \\
\hline Biogas & 17.7 & 57.4 & 81.5 & 57 & 0.11 & 5.4 \\
\hline LPG burning & 45.8 & 53.6 & 139 & 8.9 & 0.82 & 6.0 \\
\hline
\end{tabular}

\footnotetext{
${ }^{1}$ Smith et al., 2000; Zhang et al., 2000.
} 
Table 3. Emission factors of solid, liquid fractions and biogas digestate produced from pig waste during storage

\begin{tabular}{|c|c|c|c|c|}
\hline Criteria & Values & Range & Units & References \\
\hline \multicolumn{5}{|c|}{ Solid manure (non-biogas farms) } \\
\hline $\mathrm{NH}_{3}-\mathrm{N}$ & 0.308 & & $\mathrm{~kg} \mathrm{NH}_{3}-\mathrm{N}(\mathrm{kg} \mathrm{N} \text { excreted })^{-1}$ & Webb et al. (2012) \\
\hline $\mathrm{N}_{2} \mathrm{O}-\mathrm{N}$ & 0.005 & $0.0027-0.01$ & $\mathrm{~kg} \mathrm{~N}_{2} \mathrm{O}-\mathrm{N}(\mathrm{kg} \mathrm{N} \text { excreted })^{-1}$ & Eggleston et al. (2006) \\
\hline $\mathrm{CH}_{4}-\mathrm{C}$ & 0.008 & & $\mathrm{~kg} \mathrm{CH}_{4}(\mathrm{~kg} \text { volatile solid })^{-1}$ & Eggleston et al. (2006) \\
\hline $\mathrm{CO}_{2}-\mathrm{C}$ & 0.015 & $0.012-0.018$ & $\mathrm{~kg} \mathrm{CH}_{4}(\mathrm{~kg} \text { dry matter })^{-1}$ & Vu et al. $(2012 d)$ \\
\hline \multicolumn{5}{|c|}{ Liquid manure (non-biogas farms) } \\
\hline $\mathrm{NH}_{3}-\mathrm{N}$ & 0.004 & $0.321-0.381$ & Fraction of TAN & See calculation above \\
\hline $\mathrm{N}_{2} \mathrm{O}-\mathrm{N}$ & 0 & & $\mathrm{~kg} \mathrm{~N}_{2} \mathrm{O}-\mathrm{N}(\mathrm{kg} \mathrm{N} \text { excreted })^{-1}$ & Velthof et al. (2005); Eggleston et al. (2006) \\
\hline $\mathrm{CH}_{4}-\mathrm{C}$ & 0.005 & $0.042-0.055$ & $\mathrm{~kg} \mathrm{CH}_{4}(\mathrm{~kg} \text { dry matter })^{-1}$ & Vu et al. $(2012 d)$ \\
\hline $\mathrm{CO}_{2}-\mathrm{C}$ & 0.015 & $0.012-0.018$ & $\mathrm{~kg} \mathrm{CH}_{4}(\mathrm{~kg} \text { dry matter })^{-1}$ & Vu et al. (2012d) \\
\hline \multicolumn{5}{|c|}{ Digestate (Biogas farms) } \\
\hline $\mathrm{NH}_{3}-\mathrm{N}$ & 0.052 & & Fraction of TAN & See calculation above \\
\hline $\mathrm{N} 2 \mathrm{O}-\mathrm{N}$ & 0 & & $\mathrm{~kg} \mathrm{~N}_{2} \mathrm{O}-\mathrm{N}(\mathrm{kg} \mathrm{N} \text { excreted })^{-1}$ & Data connected to Vu et al. (2014) \\
\hline $\mathrm{CH}_{4}-\mathrm{C}$ & 0.20 & & Fraction of potential $\mathrm{CH}_{4}$ & UNFCCC/CCNUCC (2012) \\
\hline $\mathrm{CO}_{2}-\mathrm{C}$ & $40 / 60$ & & $\mathrm{CH}_{4}$ to $\mathrm{CO}_{2}$ ratio & Sommer et al. (2007) \\
\hline
\end{tabular}

TAN, total ammonical nitrogen.

$\mathrm{CH}_{4}$ to $\mathrm{kg} \mathrm{CH}$ and $\mathrm{MCF}$ is the $\mathrm{CH}_{4}$ conversion factor of 0.04 at an average temperature of $24^{\circ} \mathrm{C}$. This results in a $\mathrm{CH}_{4}$ emission factor of $0.0078 \mathrm{~kg} \mathrm{CH}_{4} \mathrm{~kg}^{-1}$ volatile solid.

During liquid manure storage, the emissions of $\mathrm{N}_{2} \mathrm{O}$ are small and assumed to be zero (Velthof et al., 2005; Eggleston et al., 2006). For digestate storage, emissions of $\mathrm{N}_{2} \mathrm{O}$ are also very small and close to the detection limit ( $\mathrm{Vu}$ et al., 2012a). Here the emission of $\mathrm{N}_{2} \mathrm{O}$ was assumed to be zero during the storage of liquid manure and digestate. In addition to $\mathrm{N}_{2} \mathrm{O}$ and $\mathrm{NH}_{3}$ losses, nitrogen is also lost as $\mathrm{N}_{2}$. This is of no environmental concern, but reduces the amount of nitrogen available at later stages. The fraction of total $\mathrm{N}$ lost from covered slurry storage was 0.25 to 0.30 , while from uncovered slurry it was 0.60 to 0.70 (Tran et al., 2011). Data from the study by Vu and Dinh (2012) showed that the proportion of liquid manure covered during storage was $80 \%$, while $20 \%$ was not covered. Therefore, a weighted average $\mathrm{N}$ loss during liquid storage was calculated to be 0.35 . This total $\mathrm{N}$ loss was used to estimate the loss of $\mathrm{N}_{2}$ by subtracting the loss of ammonia. The $\mathrm{CH}_{4}$ and $\mathrm{CO}_{2}$ emission factors were calculated from urine and feces accumulation in a manure pit for 28 days ( $\mathrm{Vu}$ et al., 2012d). On average, $\mathrm{CH}_{4}$ and $\mathrm{CO}_{2}$ emissions from $2.81 \mathrm{~kg}$ slurry of $14.5 \%$ dry matter content were $0.005 \mathrm{CH}_{4}(\mathrm{~kg}$ dry matter $)^{-1}$, and $0.015 \mathrm{~kg} \mathrm{CO}_{2}(\mathrm{~kg} \text { dry matter })^{-1}$, which were assumed for liquid manure storage in this study.

$\mathrm{NH}_{3}$ emission during storage was calculated assuming that the process is driven by the concentration gradient between the $\mathrm{NH}_{3}$ in the air adjacent to the surface $\left(\mathrm{NH}_{3}[\mathrm{~g}]\right)$ and that in the ambient atmosphere $\left(\mathrm{NH}_{3, \mathrm{a}}\right)$. The flux of $\mathrm{NH}_{3}$ was calculated by the equation given by Olesen and Sommer (1993): $\mathrm{FA}=\mathrm{K}(\mathrm{u}) \mathrm{A}\left(\left[\mathrm{NH}_{3}\{\mathrm{~g}\}\right]-\mathrm{NH}_{3}, \mathrm{a}\{\mathrm{g}\}\right)$ where $\mathrm{K}(\mathrm{u})$ is a transport coefficient $\left(\mathrm{m} \cdot \mathrm{s}^{-1}\right)$, which is affected by diffusion and convection in air and is mainly dependent on wind speed, surface roughness and temperature, $\mathrm{A}$ is the surface area of the storage tank and $\mathrm{NH}_{3}(\mathrm{~g})$ is the equilibrium concentration of the $\mathrm{NH}_{3}$ concentration in the air immediately over the gas - liquid interphase $\left(\mathrm{mol} \cdot \mathrm{L}^{-1}\right.$ or $\left.\mathrm{g} \cdot \mathrm{N} \cdot \mathrm{L}^{-1}\right) \cdot \mathrm{NH}_{3 \mathrm{a}}(\mathrm{g})$ is insignificant in relation to $\mathrm{NH}_{3}(\mathrm{~g})$. The concentration of gaseous components $\mathrm{NH}_{3}(\mathrm{~g})$ in the air just above the liquid surface is proportional to the activity of the component in the solution because equilibrium is attained instantaneously. The transfer coefficient $\mathrm{K}(\mathrm{u})$ $\left(\mathrm{m} \cdot \mathrm{s}^{-1}\right.$ ) for $\mathrm{NH}_{3}$ transfer from a source of $\mathrm{NH}_{3}$ to the air can be calculated with the equation given by Montes et al. (2009) as a function of temperature, wind speed and length of the emitting surface. Using the current data for total ammonical nitrogen (TAN) content of digestate and liquid manure and $\mathrm{pH}$, monthly average wind speed and temperature for Hanoi, a surface slurry area of $1.52 \mathrm{~m}^{2}$, a depth of $0.95 \mathrm{~m}$ and a flow of manure of $0.217 \mathrm{~m}^{3} \cdot \mathrm{d}^{-1}(\mathrm{Vu}$ et al., 2012b), this resulted in a fraction of TAN lost as $\mathrm{NH}_{3}$ of $0.4 \%$ of TAN for liquid manure and $5.2 \%$ for digestate storage.

The $\mathrm{CH}_{4}$ emission from the digestate storage was calculated using the default fraction, which is 0.2 of total $\mathrm{CH}_{4}$ produced in the digester for conventional biogas (UNFCCC/CCNUCC, 2012). The $\mathrm{CO}_{2}$ emission was calculated using $\mathrm{CH}_{4}$ to $\mathrm{CO}_{2}$ ratio of $40 / 60$ (Sommer et al., 2007).

During and after application of manure on crops, the most important emissions are gaseous loss of $\mathrm{NH}_{3}$ and $\mathrm{N}_{2} \mathrm{O}$ and leaching of $\mathrm{NO}_{3}{ }^{-}$. In addition, the application of manure replaces fertilizers and saves the emissions associated with their production and application. Emissions factors and data for calculation of substitution are shown in Table 4. The 
Table 4. Emission factors for nitrous oxide, ammonia and nitrate leaching and plant uptake after application of manure and mineral fertilizer on rice-rice-corn crops or vegetable gardens

\begin{tabular}{|c|c|c|c|c|}
\hline Criteria & Values & Range & Units & References \\
\hline \multicolumn{5}{|c|}{ 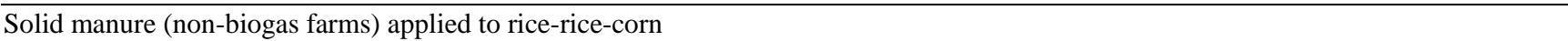 } \\
\hline $\mathrm{NH}_{3}-\mathrm{N}$ & 0.102 & $0.071-0.133$ & $\mathrm{~kg} \mathrm{NH}_{3}-\mathrm{N}(\mathrm{kg} \mathrm{N} \text { applied })^{-1}$ & Watanabe et al. (2009) \\
\hline $\mathrm{N}_{2} \mathrm{O}-\mathrm{N}$ & 0.005 & & $\mathrm{~kg} \mathrm{~N}_{2} \mathrm{O}-\mathrm{N}(\mathrm{kg} \mathrm{N} \text { applied })^{-1}$ & $\begin{array}{l}\text { Calculated as average of } 2 \text { times emission factor of } 0.003 \\
\text { (for rice) and } 1 \text { times emission factor of } 0.01 \text { (for corn) } \\
\text { (Eggleston et al., 2006) }\end{array}$ \\
\hline Leaching $\mathrm{N}$ & 0.243 & $0.202-0.324$ & $\mathrm{~kg} \mathrm{NO}_{3}-\mathrm{N}(\mathrm{kg} \mathrm{N} \text { applied })^{-1}$ & $\begin{array}{l}\text { Calculated as average leaching per applied manure } \mathrm{N} \\
\text { from the medium manure } \mathrm{N} \text { treatment with } 262.1 \mathrm{~kg} \mathrm{~N} \text {. } \\
\mathrm{ha}^{-1} \cdot \text { year }^{-1} \text { (Mai et al., 2010) }\end{array}$ \\
\hline Uptake N & 0.283 & $0.17-0.37$ & $\operatorname{kg~N}$ uptake (kg N applied $)^{-1}$ & Calculated as average $\mathrm{N}$ uptake values (Tran et al., 2012) \\
\hline $\mathrm{CH}_{4}-\mathrm{C}$ & 4.08 & & $\mathrm{~kg} \mathrm{CH}_{4}-\mathrm{C}$ (ton solid manure) $)^{-1}$ & Vu et al. (2014) \\
\hline \multicolumn{5}{|c|}{ Mineral fertilizer applied to rice-rice-corn } \\
\hline $\mathrm{NH}_{3}-\mathrm{N}$ & 0.24 & 0.095-0.109 & $\mathrm{kg} \mathrm{NH}_{3}-\mathrm{N}(\mathrm{kg} \mathrm{N} \text { applied })^{-1}$ & Sommer et al. (2004), \\
\hline $\mathrm{N}_{2} \mathrm{O}-\mathrm{N}$ & 0.003 & & $\mathrm{~kg} \mathrm{~N}_{2} \mathrm{O}-\mathrm{N}(\mathrm{kg} \mathrm{N} \text { applied })^{-1}$ & $\begin{array}{l}\text { Calculated as average of } 2 \text { times emission factor of } 0.003 \\
\text { and } 1 \text { times emission factor of } 0.01 \text { (Eggleston et al., } \\
2006 \text { ) }\end{array}$ \\
\hline Leaching $\mathrm{N}$ & 0.243 & $0.202-0.324$ & $\mathrm{~kg} \mathrm{NO}_{3}-\mathrm{N}(\mathrm{kg} \mathrm{N} \text { applied })^{-1}$ & $\begin{array}{l}\text { Calculated as average leaching per applied mineral } \\
\text { nitrogen from medium mineral } \mathrm{N} \text { treatment of } 262.1 \mathrm{~kg} \\
\mathrm{~N} \cdot \mathrm{ha}^{-1} \cdot \text { year }^{-1} \text { (Mai et al., 2010) }\end{array}$ \\
\hline Uptake N & 0.373 & $0.25-0.49$ & $\operatorname{kg~N}$ uptake (kg N applied) ${ }^{-1}$ & Calculated as average $\mathrm{N}$ uptake values (Tran et al., 2012) \\
\hline $\mathrm{CH}_{4}-\mathrm{C}$ & 0 & & & Calculated (Vu et al., 2014) \\
\hline \multicolumn{5}{|c|}{ Liquid manure (non-biogas) and digestate (biogas farms) applied to vegetable gardens } \\
\hline $\mathrm{NH}_{3}-\mathrm{N}$ & 0.33 & & $\mathrm{~kg} \mathrm{NH}_{3}-\mathrm{N}(\mathrm{kg} \mathrm{TAN})^{-1}$ & Sogaard et al., (2002) \\
\hline $\mathrm{N}_{2} \mathrm{O}-\mathrm{N}$ & 0.01 & $0.003-0.03$ & $\mathrm{~kg} \mathrm{~N}_{2} \mathrm{O}-\mathrm{N}(\mathrm{kg} \mathrm{N} \text { applied })^{-1}$ & Eggleston et al. (2006) \\
\hline Leaching $\mathrm{N}$ & 0.165 & & $\mathrm{~kg} \mathrm{NO}_{3}-\mathrm{N}(\mathrm{kg} \mathrm{N} \text { applied })^{-1}$ & Mai et al. (2010) \\
\hline Uptake N & 0.328 & & $\operatorname{kg~N}$ uptake (kg N applied) $)^{-1}$ & $\begin{array}{l}\text { Calculated as an average } \mathrm{N} \text { uptake from solid manure } \\
\text { and mineral fertilizer (Tran et al., 2012) }\end{array}$ \\
\hline \multicolumn{5}{|c|}{ Mineral fertilizer applied to vegetable gardens } \\
\hline $\mathrm{NH}_{3}-\mathrm{N}$ & 0.24 & & $\mathrm{~kg} \mathrm{NH}_{3}-\mathrm{N}(\mathrm{kg} \mathrm{N} \text { applied })^{-1}$ & Sommer et al. (2004) \\
\hline $\mathrm{N}_{2} \mathrm{O}-\mathrm{N}$ & 0.01 & $0.003-0.03$ & $\mathrm{~kg} \mathrm{~N}_{2} \mathrm{O}-\mathrm{N}(\mathrm{kg} \mathrm{N} \text { applied })^{-1}$ & Eggleston et al. (2006) \\
\hline Leaching $\mathrm{N}$ & 0.165 & & $\mathrm{~kg} \mathrm{NO}_{3}-\mathrm{N}(\mathrm{kg} \mathrm{N} \text { applied })^{-1}$ & Mai et al. (2010) \\
\hline Uptake N & 0.373 & & $\operatorname{kg~N}$ uptake $(\mathrm{kg} \mathrm{N} \text { applied })^{-1}$ & Calculated as average $\mathrm{N}$ uptake values (Tran et al., 2012) \\
\hline
\end{tabular}

avoided mineral fertilizers were assumed to be urea (46\% $\mathrm{N})$, single superphosphate $(6.9 \% \mathrm{P})$ and potassium chloride $(50 \% \mathrm{~K})$ because they are the most widely used fertilizers in Vietnam. The fertilizer replacement value for $\mathrm{P}$ was considered to be $100 \%$ which is a plausible assumption on longer time scales (Huang et al., 2011). The fertilizer replacement value for $\mathrm{K}$ was also assumed to $100 \%$, which is realistic as $\mathrm{K}$ is not organically bound.

When $\mathrm{C}$ is added to a soil, some carbon will not be released within the time boundary of the study and will still be bound in the soil, i.e. after 100 years. As the carbon in the manure is considered to be $\mathrm{CO}_{2}$ neutral, the stored carbon is sequestered. In long term-experiments with animal manure, around $15 \%$ of the carbon is usually sequestered (Johnston et al., 2009). In the current study this was used as the sequestration factor for undigested manure. For digested manure the $15 \%$ was scaled with the relative stability for digestate in relation to undigested manure found in short-term experiments. Thomsen et al. (2013) found a short-term sequestration factor of $48 \%$ of added $\mathrm{C}$ sequestered for undigested manures and $78 \%$ for digestate. This therefore resulted in a sequestration factor of $24 \%$ for digested manure.

$\mathrm{NH}_{3}$ emissions after the application of farmyard manure are relatively low because most of the nitrogen is in organic form and because of the standing water in the rice field (Watanabe et al., 2009). In accordance with this study, an $\mathrm{NH}_{3}$ emission factor of $0.102 \mathrm{~kg} \mathrm{NH} \mathrm{NH}_{3} \mathrm{~N}(\mathrm{~kg} \cdot \mathrm{N})^{-1}$ was assumed for the application of solid manure. For the urea fertilizer, Sommer et al. (2004) found ammonia emissions of $24 \% \mathrm{NH}_{3}-\mathrm{N}(\mathrm{kg} \cdot \mathrm{N})^{-1}$ on ordinary crops and from $10 \%$ to $40 \% \mathrm{NH}_{3}-\mathrm{N}(\mathrm{kg} \cdot \mathrm{N})^{-1}$ for rice depending on water status and growth stage. An average value of $24 \% \mathrm{NH}_{3}-\mathrm{N}(\mathrm{kg} \cdot \mathrm{N})^{-1}$ was assumed for the rice-rice-corn rotation.

The $\mathrm{N}_{2} \mathrm{O}$ emission factors were estimated by the IPCC to be $0.01 \mathrm{~kg} \mathrm{~N} \mathrm{~N}_{2} \mathrm{O}-\mathrm{N}(\mathrm{kg} \cdot \mathrm{N})^{-1}$ for crop fields and $0.003 \mathrm{~kg}$ $\mathrm{N}_{2} \mathrm{O}-\mathrm{N}(\mathrm{kg} \cdot \mathrm{N})^{-1}$ for flooded rice fields (Eggleston et al., 2006). Therefore, the emission factor for rice-rice-corn 
cropping sequences was calculated as a weighted average (average of two times the emission factor of 0.003 and one times the emission factor of 0.01 ), resulting in a value of $0.005 \mathrm{~kg} \mathrm{~N} \mathrm{O}_{2} \mathrm{O}-\mathrm{N}(\mathrm{kg} \cdot \mathrm{N})^{-1}$.

In a rice field, the $\mathrm{CH}_{4}$ emission was $244 \mathrm{~kg} \mathrm{CH}_{4} \cdot \mathrm{ha}^{-1}$ if mineral fertilizer was applied at a rate of $105 \mathrm{~kg} \mathrm{~N} \cdot \mathrm{ha}^{-1}$, while it was $301 \mathrm{~kg} \mathrm{CH}_{4} \cdot \mathrm{ha}^{-1}$ from a combination of $45 \mathrm{~kg}$ $\mathrm{N} \cdot \mathrm{ha}^{-1}$ mineral fertilizer and $100 \mathrm{~kg} \mathrm{~N} \cdot \mathrm{ha}^{-1}$ solid manure (8,000 $\mathrm{kg}$ of solid manure) ( $\mathrm{Vu}$ et al., 2014). It is assumed that the increased $\mathrm{CH}_{4}$ emission in the combined treatment was due to the added solid manure, resulting in an emission of $57 \mathrm{~kg} \mathrm{CH} \cdot \mathrm{ha}^{-1}$. However, as the $\mathrm{CH}_{4}$ emissions from arable fields are negligible (Sommer et al., 1996), the emission for rice-rice-corn cropping sequences was calculated as a weighted average of two times the emission value of $57 \mathrm{~kg} \mathrm{CH} \cdot \mathrm{Ca}^{-1}$ divided by three crops (rice-ricecorn). This means that $1,000 \mathrm{~kg}$ of solid manure added to the rice-rice-corn crop rotation to replace mineral fertilizer could result in additional emissions up to $4.76 \mathrm{~kg} \mathrm{CH}$, which is equivalent to $4.08 \mathrm{~kg} \mathrm{CH}_{4}-\mathrm{C}$. The $\mathrm{CH}_{4}$ emissions associated with mineral fertilizer application was assumed to be zero.

The leaching and runoff of $\mathrm{NO}_{3}^{-}$after application was $85 \mathrm{~kg} \mathrm{~N} \cdot \mathrm{ha}^{-1} \cdot$ year $^{-1}$ for medium $\mathrm{N}$ input of $262.1 \mathrm{~kg}$ $\mathrm{N} \cdot \mathrm{ha}^{-1} \cdot$ year $^{-1}$ and was $106 \mathrm{~kg} \mathrm{~N} \cdot \mathrm{ha}^{-1} \cdot$ year $^{-1}$ for high $\mathrm{N}$ inputs of $524 \mathrm{~kg} \mathrm{~N} \cdot \mathrm{ha}^{-1} \cdot$ year $^{-1}$ (Mai et al., 2010). Assuming the $\mathrm{N}$ input applied is the average of high and medium, the leaching of $\mathrm{NO}_{3}{ }^{-}$after application was calculated as the average leaching of $\mathrm{NO}_{3}^{-}$from medium and high $\mathrm{N}$ inputs. This means that the leaching factor for $\mathrm{NO}_{3}{ }^{-}$is $0.243 \mathrm{~kg}$ $\mathrm{NO}_{3}^{-}-\mathrm{N}$ (kg N applied) ${ }^{-1}$ and the same factor was assumed for mineral fertilizer and solid manure in this study.

The $\mathrm{N}$ uptake by corn, spring rice and summer rice was $0.49,0.25$, and $0.38 \mathrm{~kg} \mathrm{~N}$ (kg N mineral fertilizer applied $)^{-1}$ respectively (Tran et al., 2012). This means that the average $\mathrm{N}$ uptake for rice-rice-corn crop rotation was $0.373 \mathrm{~kg}$ $\mathrm{N} \cdot \mathrm{kg}^{-1} \mathrm{~N}$ applied in mineral fertilizer. For solid manure (Tran et al., 2012), it was also reported that the average $\mathrm{N}$ uptake from $5,000 \mathrm{~kg}$ manure $\mathrm{crop}^{-1} \cdot \mathrm{ha}^{-1}$ was $0.34 \mathrm{~kg} \mathrm{~N}(\mathrm{~kg}$ $\mathrm{N}$ applied $)^{-1}$ and from $10,000 \mathrm{~kg}$ manure $\mathrm{crop}^{-1} \cdot \mathrm{ha}^{-1}$ was $0.22 \mathrm{~kg} \mathrm{~N}$ (kg N applied) $)^{-1}$. In this study, $\mathrm{N}$ uptake by crops was calculated as the average $\mathrm{N}$ uptake of these values. This results in an uptake of $0.283 \mathrm{~kg} \mathrm{~N} \cdot \mathrm{kg}^{-1} \mathrm{~N}$ applied in solid manure.

Mineral fertilizer equivalencies (MFE) for nitrogen is a measure of the ability of a fertilizer to supply nitrogen to crops compared with mineral fertilizer, and were used to calculate the amount of mineral fertilizer which was saved as a consequence of the application of different fertilizers. Therefore, MFE of the solid manure was estimated to be the plant uptake of solid fraction manure of $0.283 \mathrm{~kg} \mathrm{~N} \cdot \mathrm{kg}^{-1} \mathrm{~N}$ divided by the plant uptake of $0.373 \mathrm{~kg} \mathrm{~N} \cdot \mathrm{kg}^{-1} \mathrm{~N}$ applied for the mineral fertilizer. This results in an MFE of $76 \%$ for the solid manure. This is somewhat higher than the MFE values typically found for single applications of solid manures and higher than expected from general solid manure studies of MFE values (Delin et al., 2012), but the Tran et al. (2012) study also represented the accumulated residual MFE value of three consecutive solid manure applications, which they showed could be as high as $24 \%$, and the solid manure $\mathrm{C} / \mathrm{N}$ ratios were relatively low (14 to 16) and the proportion if $\mathrm{NH}_{4}-\mathrm{N}$ in total $\mathrm{N}$ relatively high $(33 \%)$.

Most farmers apply liquid manure and digestate to vegetable gardens by surface spreading. Cumulative $\mathrm{NH}_{3}$ emissions after surface spreading of liquid manure varies between $10 \%$ and $70 \%$ of TAN (Sommer and Hutchings, 2001). A similar $\mathrm{NH}_{3}$ loss for digestate is also expected (Chantigny et al., 2007). The ammonia loss from fieldapplied animal manure model was used to estimate ammonia emissions for both liquid manure and digestate to be $33 \%$ of TAN using the climate data, soil characteristics and slurry composition previously described (Sogaard et al., 2002a). For urea in the vegetable gardens the previously used value of $24 \% \mathrm{NH}_{3}-\mathrm{N}(\mathrm{kg} \mathrm{N})^{-1}$ was used (Sommer et al., 2004). The lower emission from mineral fertilizer is in accordance with Huijsmans et al. (2003) and De Vries et al. (2012) who observed lower emissions from mineral fertilizers compared with animal slurries and digestates.

The $\mathrm{N}_{2} \mathrm{O}$ emission factor for $\mathrm{N}$ additions from mineral fertilizer and organic manure was $0.01 \mathrm{~kg} \mathrm{~N}_{2} \mathrm{O}-\mathrm{N}(\mathrm{kg} \mathrm{N})^{-1}$ (Eggleston et al., 2006). This value was used as the $\mathrm{N}_{2} \mathrm{O}$ emission factor from liquid manure, digestate and mineral fertilizer applied on vegetable gardens in this study.

Leaching of $\mathrm{NO}_{3}{ }^{-}$after application of mineral fertilizer was considered equal to leaching from liquid manure. The leaching of $\mathrm{NO}_{3}^{-}$from vegetable gardens (cabbage with 6 harvests year ${ }^{-1}$ ) with a fertilizer $\mathrm{N}$ application of $681.6 \mathrm{~kg} \mathrm{~N}$ $\mathrm{ha}^{-1} \cdot$ year $^{-1}$ was 112 to $115 \mathrm{~kg} \mathrm{~N} \cdot \mathrm{ha}^{-1} \cdot$ year $^{-1}$ (Mai et al., 2010). This means that the leaching factor was $0.165 \mathrm{~kg}$ $\mathrm{NO}_{3}^{-}-\mathrm{N}(\mathrm{kg} \mathrm{N})^{-1}$ and was assumed to be similar for liquid manure, digestate and mineral fertilizer.

The crop $\mathrm{N}$ uptake for liquid manure was also used for digestate because $\mathrm{N}$ fertilizer replacement values of digested manure increase in the first year after application, but decline more rapidly afterwards and do not differ in the long term (Schröder et al., 2007). Losak et al. (2011) reported that digestate fertilization resulted in the weight of kohlrabi bulbs being comparable to the weight obtained when a similar rate of nutrients were applied in the form of mineral fertilizers. Therefore, the $\mathrm{N}$ uptake of $0.373 \mathrm{~kg} \mathrm{~N}$ $(\mathrm{kg} \mathrm{N} \text { applied })^{-1}$ for mineral fertilizer was also assumed for liquid manure and digestate. 

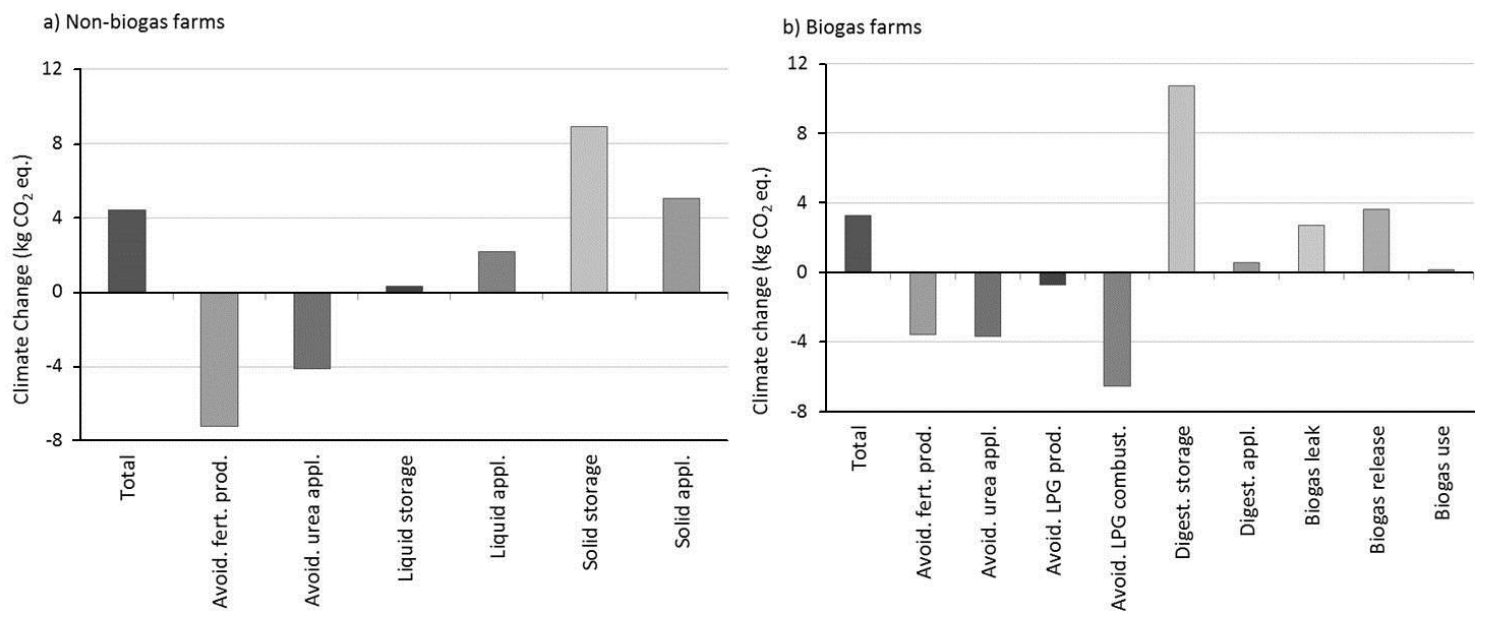

Figure 2. Contribution of a) non-biogas and b) biogas manure management systems to global warming potential throughout their life cycles.

\section{RESULTS}

\section{Global warming potential}

When traditional management methods were used, the handling of one functional unit of manure resulted in an impact of $4.4 \mathrm{~kg} \mathrm{CO}_{2}$ equivalents (Figure 2a). The greatest proportions of emissions were $\mathrm{CH}_{4}$ emissions during solid storage and $\mathrm{N}_{2} \mathrm{O}$ emissions after field application. Some emissions could be prevented due to the avoidance of fertilizer production, but not enough to compensate for the emissions during storage and after field application.

The handling of a functional unit of manure resulted in a global warming potential of $3.2 \mathrm{~kg} \mathrm{CO}$ equivalents in a manure management system with biogas (Figure 2b). The greatest emissions in this system are associated with $\mathrm{CH}_{4}$ from digestate storage. In addition, the loss of $\mathrm{CH}_{4}$ through leaks and the intentional release of biogas has a considerable impact. There were also significant savings in terms of impacts, mainly as a result of saving LPG gas that was substituted by the biogas produced, but also generated by avoiding fertilizer production and the application of urea.

The results clearly show that emissions of $\mathrm{CH}_{4}$, mainly from digestate storage and the intentional release of biogas when production exceeds consumption, may seriously compromise any benefits in terms of global warming by outweighing any savings made by replacing alternative fuels with biogas.

\section{Fossil fuel depletion potential}

Figure 3 shows that both manure handling systems represent net reductions in fossil fuel depletion potential. The reason for this is that manure is a useful resource that can be used to replace fuels and fertilizers. The non-biogas management system resulted in greater savings than the biogas management system. Although the biogas replaces LPG production, non-biogas farms saved more fossil resources since this system features a greater recycling of nutrients and thus leads to replacement of more chemical fertilizers whose production requires considerable energy. These results are obviously highly dependent on the assumptions regarding the substitution of mineral fertilizer and the fact that these substitutions actually happen. However, despite this uncertainty, the result clearly shows that the substitution of fertilizers is also important in terms of fossil fuel depletion potential.

\section{Freshwater eutrophication potential}

In the ReCiPe impact assessment method, it is assumed that biological production in fresh water ecosystems is limited by $\mathrm{P}$ availability. Therefore, there is no effect of emissions from other nutrients in this category. The biggest environmental burden on fresh water eutrophication comes from the discharge of liquid manure and digestate in both manure management systems (Table 5). The level of $\mathrm{P}$ discharged from the biogas system was five times higher

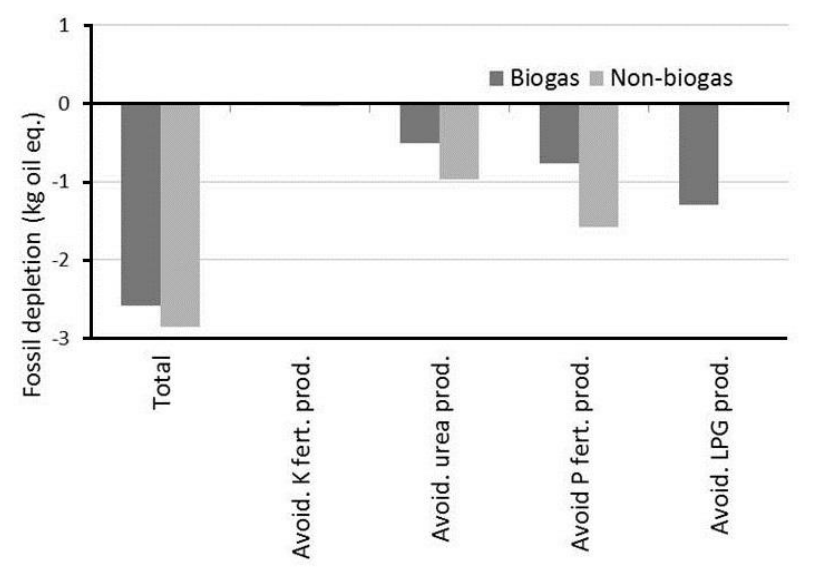

Figure 3. Contribution of biogas farms and non-biogas manure management systems to fossil fuel depletion potential throughout the manure management life cycle. 
Table 5. Contribution of biogas farms and non-biogas farms to freshwater eutrophication potential throughout manure management, from storage to application, in $\mathrm{kg} \mathrm{P}$ eq

\begin{tabular}{lcccc}
\hline Farm types & Total phosphorus & Avoided fertilizer production & Liquid/digestate discharge & Solid discharge \\
\hline Non-biogas farms & 0.128 & -0.003 & 0.115 & 0.027 \\
Biogas farms & 0.551 & -0.001 & 0.552 & \\
\hline
\end{tabular}

than that from non-biogas systems. This is mainly caused by the discharge of digestate, which is harder to recycle because of its high water content. As a result, the impact potential in this category from biogas systems was $0.551 \mathrm{~kg}$ $\mathrm{P}$ eq. per FU, while it was only $0.128 \mathrm{~kg} \mathrm{P}$ eq. per $\mathrm{FU}$ from the non-biogas system.

\section{Marine water eutrophication potential}

The ReCipe method assumes that the marine environment is $\mathrm{N}$ limited and therefore that only emissions of N-containing compounds can contribute to marine water eutrophication. The non-biogas management system contributed $0.33 \mathrm{~kg} \mathrm{~N}$ eq. per $\mathrm{FU}$ to marine water eutrophication potential (Figure 4a). The $\mathrm{N}$ content in the discharged liquid manure as well as emissions during and after application of solid manure are the largest contributors to marine water eutrophication in this system. The emission associated with liquid and solid manure application on agricultural land was $0.24 \mathrm{~kg} \mathrm{~N}$ eq. per FU, which is similar to the emissions saved by not using urea fertilizer.

The biogas manure management system contributed $0.82 \mathrm{~kg} \mathrm{~N}$ eq. per FU to marine eutrophication. The main contribution to this is through the discharged digestate. Again the emissions saved by not using urea prevent an impact similar in size to the one associated with digestate application. As with the non-biogas management system, the two processes of digestate storage and digestate application made a negligible contribution to marine water eutrophication.

As summarized in Figure 5, the biogas manure

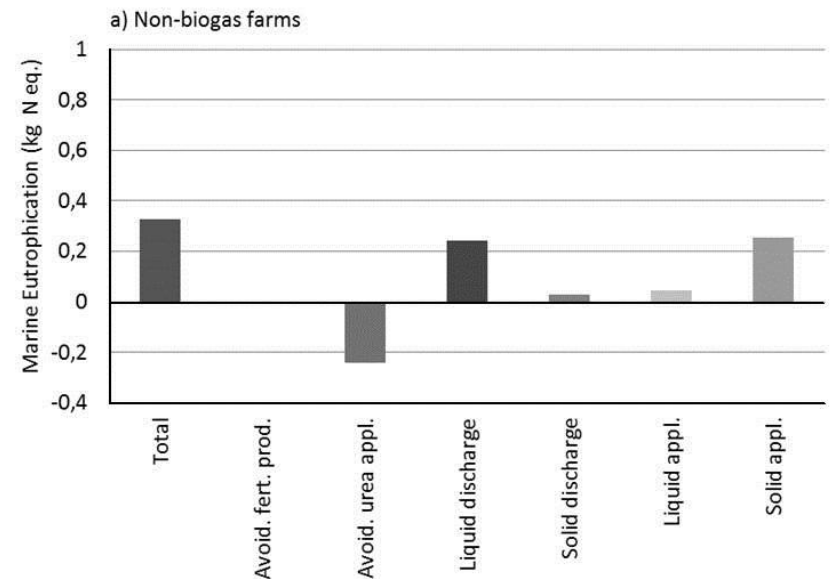

management system is shown to have slightly smaller environmental impacts than the non-biogas system with respect to the climate change category. For fossil fuel depletion potential, both types of farms save on impacts, but the non-biogas system saves more energy than the biogas system. With regards to eutrophication of freshwater and marine water, non-biogas farms have clear advantages over biogas farms, which potentially contribute more than four times and almost three times as much respectively.

\section{Sensitivity analysis}

It is obvious that fugitive emissions of $\mathrm{CH}_{4}$ and the reduced recycling of nutrients compromise the possible environmental benefits of biogas technology in this assessment. Reductions of emissions from the storage of digestate would require longer hydraulic retention times in the digester to reduce $\mathrm{CH}_{4}$ production potential before the digestate enters the storage facilities. This is complicated to achieve. Reducing the intentional release of biogas by flaring the biogas instead of releasing it should be relatively easy, provided farmers/digester operators are properly instructed, and could be done without difficulty or negative implications. Therefore, a scenario was tested in which all the biogas that would otherwise intentionally be released was flared. It is also evident that the discharge of large amounts of digestate is problematic. A scenario was therefore tested where half of the discharged digestate was recycled on agricultural fields instead, which should be possible to achieve if proper incentives are given.

Responses in the environmental impact categories

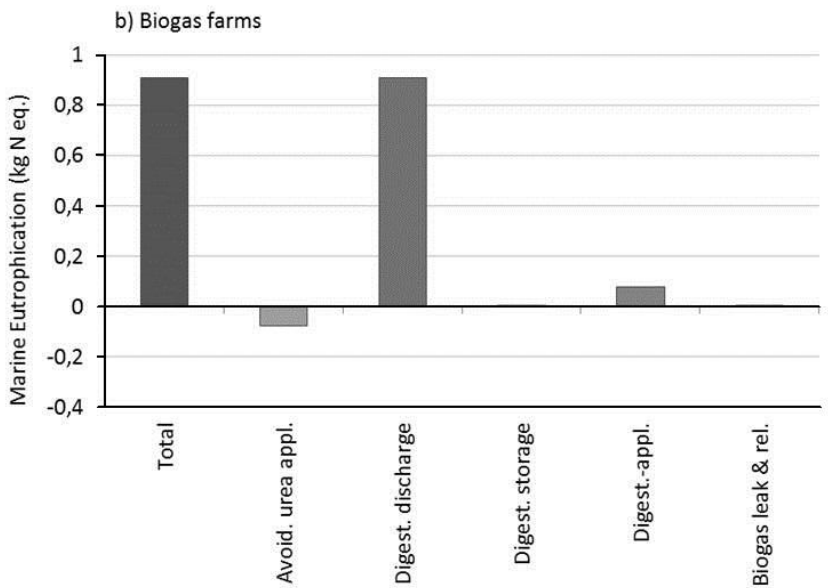

Figure 4. Contribution of a) non-biogas and b) biogas manure management systems to marine water eutrophication potential throughout the manure life cycle. 


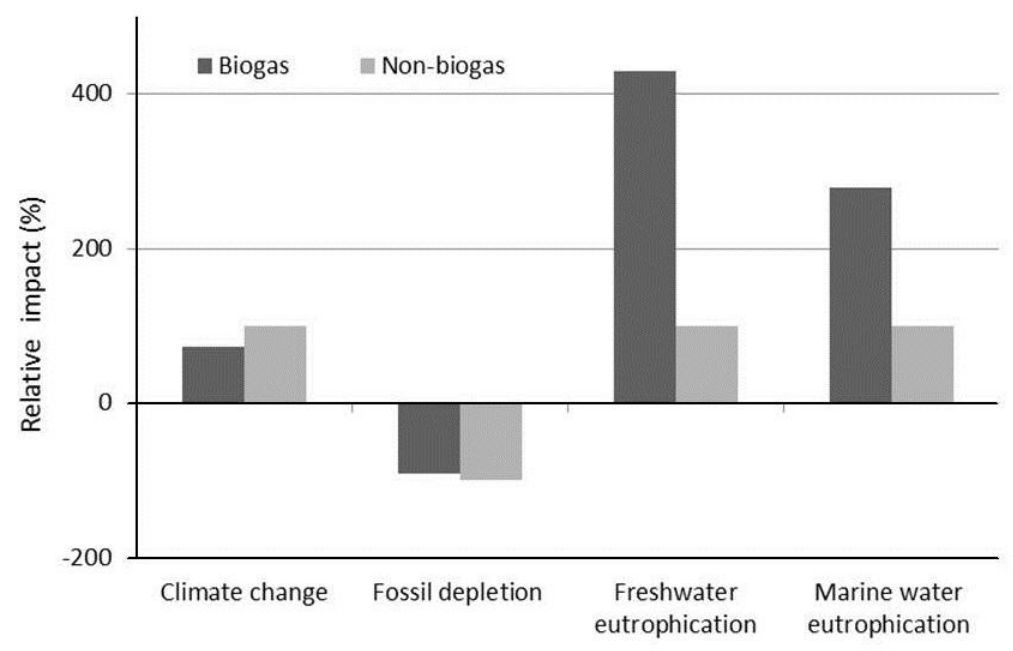

Figure 5. Relative impact of non-biogas and biogas farms in four impact categories. The non-biogas farm is shown as $100 \%$.

resulting from the flaring of biogas that would have otherwise been released are illustrated in Table 2. The result showed that the climate change impacts of the biogas management system are now significantly reduced compared to the non-biogas system, making the biogas system clearly favorable in terms of impacts in the climate change category. However, this is not the case for the remaining environmental impact categories-fossil fuel depletion, freshwater eutrophication and marine water eutrophication-which remain unaffected. Biogas is still associated with having greater impacts.

Scenarios were tested with i) no intentional release of excess biogas ii) $50 \%$ reduction in digestate discharged into environment and iii) no intentional release of excess biogas and $50 \%$ reduction in digestate discharged into environment

The reduction of the digestates discharged from the biogas management system reduced both global warming and fossil fuel depletion compared to the non-biogas system. In terms of climate change, the positive and negative impacts of the biogas system now practically cancel each other out. However, the biogas management system still contributes more to freshwater and marine water eutrophication than the non-biogas system (Table 6). Reducing the impacts in these categories to below the impacts of non-biogas management systems would therefore recycling of all the digestate, with no discharge at all.

Responses in the environmental impact categories resulting from the combined flaring of biogas and reduction of the digestates being discharged would result in a significant reduction in the emission of greenhouse gases from the system with a household biogas digester compared with traditional management. However, recycling $50 \%$ of the digestates would not be as efficient as the traditional system in terms of eutrophication.

\section{DISCUSSION}

The results in the current study clearly show that the release of $\mathrm{CH}_{4}$, both through intentional release and from digestate storage, has a significant impact in terms of global warming. The calculations in this study indicated that the biogas digester helped reduce the impact on global warming, but this effect is not substantial and could easily be compromised, for example if emissions during the construction of the digester are taken into account. According to Wang and Zhang (2012), the construction of an $8 \mathrm{~m}^{3}$ biogas digester accounts for $2,357 \mathrm{~kg} \mathrm{CO}$ eq. If the digester is operated for its intended lifetime of 20 years and with a retention time of 30 days, emissions would be 1.67 $\mathrm{kg} \mathrm{CO}_{2}$ eq. per $\mathrm{FU}$ if the construction of the biogas digester is allocated to a FU in this study. This means that total

Table 6. Sensitivity analysis results for the four environmental impact categories

\begin{tabular}{|c|c|c|c|c|c|}
\hline \multirow[b]{2}{*}{ Environmental categories } & \multirow{2}{*}{$\begin{array}{l}\text { Non biogas } \\
\text { Unchanged }\end{array}$} & \multicolumn{4}{|c|}{ With biogas } \\
\hline & & Unchanged & $\begin{array}{l}\text { Flaring of } \\
\text { excess } \\
\text { biogas }\end{array}$ & $\begin{array}{c}50 \% \text { reduction } \\
\text { in discharged } \\
\text { digestate }\end{array}$ & $\begin{array}{c}\text { Flaring of excess biogas } \\
\text { and } 50 \% \text { reduction in } \\
\text { discharged digestate }\end{array}$ \\
\hline Climate change ( $\mathrm{kg} \mathrm{CO}_{2}$ eq.) & 4.414 & 3.253 & -0.339 & -1.571 & -5.163 \\
\hline Fossil depletion (kg oil eq.) & -2.861 & -2.589 & -2.589 & -3.516 & -3.516 \\
\hline Freshwater eutrophication (kg P eq.) & 0.128 & 0.550 & 0.550 & 0.274 & 0.274 \\
\hline Marine water eutrophication (kg N eq.) & 0.326 & 0.910 & 0.909 & 0.455 & 0.455 \\
\hline
\end{tabular}


emissions would be $4.93 \mathrm{~kg} \mathrm{CO}$ equivalents in a manure management system with biogas. In addition, the release of biogas is likely to be higher in some situations than estimated here. Observations from surveys on large-scale farms, mainly in southern Vietnam, clearly show that a greater proportion of biogas is released there. The problem with intentional release is therefore likely to be even greater in southern Vietnam. These factors clearly compromise the positive effect of the digesters.

Bruun et al. (2014) also concluded that the intentional release from small-scale biogas digesters was an issue, but in the current study it is shown that it is also important when the whole life cycle of the manure management chain is considered. Another LCA study of biogas digesters on small-scale farms has failed to identify this problem, because it was assumed that $\mathrm{CH}_{4}$ emissions from the digesters were zero (Chen et al., 2012). The biogas systems analyzed in that study are somewhat more advanced than the Vietnamese systems analyzed here. It is felt, however, that it is very unlikely that there are no emissions at all. Assumptions have been made that an LCA of even more advanced systems in developed countries suggests relatively small emissions. For example, De Vries et al. (2012) assumed emissions of $1.5 \%$ and Poeschl et al. (2012b) assumed losses of $1.8 \%$ for small plants and $1 \%$ for large plants. With these limited emissions, the GHG balance for these more advanced systems are more favorable and the emissions play a smaller role in the LCAs. However, fugitive emissions even for advanced and well-maintained biogas plants can in fact be significant (Flesch et al., 2011).

In the sensitivity analysis it was seen that flaring the excess biogas instead of releasing it significantly improved the environmental profile of the biogas solution in comparison with traditional manure management. An even better option than flaring biogas would be to use it for purposes where it saves on other types of fuels. It is likely that this requires the implementation of new technologies, such as systems for removing corrosive gases, mainly hydrogen sulfide $\left(\mathrm{H}_{2} \mathrm{~S}\right)$, from the gas, systems for compressing and storing the gas or distribution systems allowing the gas to be shared with neighbors (Kapdi et al., 2005). These technologies do exist, but they involve some outlay by the farmer and may therefore not be implemented unless incentives are given through legislation or subsidies.

This study also clearly indicates that the low recycling of nutrients from the digestate is highly problematic from an environmental point of view. The reason for the low recycling of nutrients in the digestate is its high water content, making it costly and logistically difficult to transport to agricultural fields, especially in regions dominated by small fields geographically spread out and a long way from the farm and the biogas digester location. Compared with the non-biogas manure management system, a considerable amount of water is used to flush the solids into the digester. This means that larger amounts of digestate have to be transported to agricultural fields that are often located a long way away. To take advantage of the biogas technologies to minimize impacts on the environment, it is therefore necessary to develop distribution systems. These would be greatly facilitated by some sort of technology that could concentrate nutrients from the digestates so that smaller quantities would have to be transported. A number of advanced options exist for the separation of digestates into liquid and solid fractions with a higher concentration of nutrients or otherwise concentrating nutrients (Hjorth et al., 2010; ten Hoeve et al., 2013). However, these options are unlikely to be applicable in small-scale farming conditions. Therefore, low-tech solutions to this problem are urgently required. Another possibility may be to feed the digestate into reed beds and recycle the sediment (Cooper, 1999; Uggetti et al., 2010). However, more simple solutions that are less costly in terms of money and labor might be easier to implement. This could include reducing the amount of washing water to get a less dilute digestate ( $\mathrm{Vu}$ et al., 2012a) and installing pumping systems that facilitate distribution to fields.

\section{CONCLUSIONS}

The results clearly indicated that losses of biogas from digesters as well as the intentional release of biogas and emissions of $\mathrm{CH}_{4}$ from manure storage compromise the beneficial effects in terms of global warming brought about by using the biogas produced to replace other fuels. Although the current results still indicate that there is an overall advantage, it is clearly diminished by these losses. In addition, the picture may be even worse in some situations, such as on large-scale farms in southern Vietnam, where the excess of biogas is likely to be greater. However, from the sensitivity analysis it is also clear that biogas digesters can become a means of reducing global warming impacts relatively easily if $\mathrm{CH}_{4}$ emissions can be kept low. Future research will therefore be needed to assess biogas release and emission from digesters and storage in order to achieve a better understanding of where and why the emissions occur. This knowledge will be helpful for proposing interventions for efficient manure management through improved biogas systems.

Furthermore the current analysis clearly demonstrates that biogas digesters are exacerbating problems with the low recycling of nutrients from animal waste. The environmental costs associated with reduced nutrient recycling caused by the digesters means that in order to make the digesters more sustainable, it is pertinent to develop better methods and technologies to ensure the recycling of nutrients contained in the digestate. 


\section{ACKNOWLEDGMENTS}

This study received financial support from Denmark's development cooperation (Danida) through the "Sustainable, Sanitary and Efficient Management of Animal Manure for Plant Nutrition", SUSANE project phase 2-research project No. J.nr.104.Dan.8.L.722 (http://www.susane.info /en/home).

\section{REFERENCES}

Bruun, S., L. S. Jensen, V. T. Khanh Vu, and S. G. Sommer. 2014. Small-scale household biogas digesters: An option for global warming mitigation or a potential climate bomb? Renew. Sustain. Energy Rev. 33:736-41.

Chantigny, M. H., D. A. Angers, P. Rochette, G. Belanger, D. Masse, and D. Cote. 2007. Gaseous nitrogen emissions and forage nitrogen uptake on soils fertilized with raw and treated swine manure. J. Environ. Qual. 36:1864-72.

Chen, S., B. Chen, and D. Song. 2012. Life-cycle energy production and emissions mitigation by comprehensive biogas - digestate utilization. Bioresour. Technol. 114:357-364.

Cooper, P. 1999. A review of the design and performance of vertical-flow and hybrid reed bed treatment systems. Water Sci. Technol. 40:1-9.

Costales, A., P. Gerber, and H. Steinfeld. 2006. Underneath the livestock revolution. Animal Production and Health Division, Food and Agriculture Organization of the United Nations, Rome, Italy.

De Vries, J. W., T. M. W. J. Vinken, L. Hamelin, and I. J. M. de Boer. 2012. Comparing environmental consequences of anaerobic mono- and co-digestion of pig manure to produce bio-energy-A life cycle perspective. Bioresour. Technol. 125:239-248.

Delin, S., B. Stenberg, A. Nyberg, and L. Brohede. 2012. Potential methods for estimating nitrogen fertilizer value of organic residues. Soil Use Manag. 28:283-291.

Department of Livestock Production. 2010. Vietnam part of annual report of the Asia biogas program. Ministry of Agriculture and Rural Development, Hanoi, Vietnam.

Department of Livestock Production. 2013. Commercial feed production in Vietnam. Ministry of Agriculture and Rural Development, Hanoi, Vietnam.

Dhingra, R., E. R. Christensen, Y. Liu, B. Zhong, C. F. Wu, M. G. Yost, and J. V. Remais. 2011. Greenhouse gas emission reductions from domestic anaerobic digesters linked with sustainable sanitation in rural China. Environ. Sci. Technol. 45:2345-2352.

Eastern Research Group. 2010. PA Consulting Group, and International Institute for Energy Conservation, Resource assessment report for livestock and agro-industrial wastes Vietnam. Methane to Markets Partnership, Hanoi, Vietnam.

Eggleston, S., L. Buendia, K. Miwa, T. Ngara, and K. Tanabe. 2006. IPCC guidelines for national greenhouse gas inventories. Institute for Global Environmental Strategies. Hayama, Japan.

European Commission. 2010. Joint Research Centre - Institute for Environment and Sustainability: International Reference Life
Cycle Data System (ILCD) Handbook - General guide for Life Cycle Assessment-Detailed guidance. 1st edn, March 2010. EUR 24708 EN. Luxembourg. Publications Office of the European Union.

Flesch, T. K., R. L. Desjardins, and D. Worth. 2011. Fugitive methane emissions from an agricultural biodigester. Biomass Bioenerg. 35:3927-3935.

Goedkoop, M., R. Heijungs, M. Huijbregts, A. De Schryver, J. Struijs, and R. van Zelm. 2009. ReCiPe 2008: A life cycle impact assessment method which comprises harmonised category indicators at the midpoint and the endpoint level. Environmental Agency, Amersfoort, the Netherlands.

Hamelin, L., M. Wesnes, H. Wenzel, and B. M. Petersen. 2011. Environmental consequences of future biogas technologies based on separated slurry. Environ. Sci. Technol. 45:58695877.

Hjorth, M., K. V. Christensen, M. L. Christensen, and S. G. Sommer. 2010. Solid liquid separation of animal slurry in theory and practice. A review. Agron. Sustain. Dev. 30:153-180.

Huang, S., Y. Ma, D. Bao, D. Guo, and S. Zhang. 2011. Manures behave similar to superphosphate in phosphorus accumulation in long-term field soils. Int. J. Plant Prod. 5:135-146.

Huijsmans, J. F. M., J. M. G. Hol, and G. D. Vermeulen. 2003. Effect of application method, manure characteristics, weather and field conditions on ammonia volatilization from manure applied to arable land. Atmos. Environ. 37:3669-3680.

ISO, 2006a. ISO 14044. Environmental management—Life cycle assessment-Requirements and guidelines. International Organisation for Standardisation, Geneva, Switzerland.

ISO, 2006b. ISO 14040. Environmental management—Life cycle assessment-Principles and framework. International Organisation for Standardisation, Geneva, Switzerland.

Johnston, A. E., P. R. Poulton, and K. Coleman. 2009. Soil organic matter: Its Importance in sustainable agriculture and carbon dioxide fluxes. Adv. Agron. 101:1-57.

Kapdi, S. S., V. K. Vijay, S. K. Rajesh, and R. Prasad. 2005. Biogas scrubbing, compression and storage: Perspective and prospectus in Indian context. Renew. Energy 30:1195-1202.

Losak, T., A. Zatloukalova, M. Szostkova, J. Hlusek, J. Fryc, and T. Vitez. 2011. Comparison of the effectiveness of digestate and mineral fertilizer on yields and quality of kohlrabi (Brassica Oleraces, L.). Acta Univ. Agric. et Silvic. Mend. Brun. 3:117122.

Mai, V. T., H. van Kaulen, and R. Roetter. 2010. Nitrogen leaching in intensive cropping systems in Tan Duong Dristrict, Red River Delta of Vietnam. Water Air Soil Pollut. 210:15-31.

Montes, F., C. A. Rotz, and H. Chaoui. 2009. Process modeling of ammonia volatilization from ammonium solution and manure surfaces: a review with recommended models. Trans. ASAE 52:1707-1720.

Olesen, J. E. and S. G. Sommer. 1993. Modelling effects of wind speed and surface cover on ammonia volatilization from stored pig slurry. Atmos. Environ. 27:2567-2574.

Park, J. B. K., R. J. Craggs, and A. N. Shilton. 2013. Investigating why recycling gravity harvested algae increases harvestability and productivity in high rate algal ponds. Water Res. 47:49044917.

Pei-dong, Z., J. Guomei, and W. Gang. 2007. Contribution to 
emission reduction of $\mathrm{CO}_{2}$ and $\mathrm{SO}_{2}$ by household biogas construction in rural China. Renew. Sustain. Energy Rev. 11:1903-1912.

Poeschl, M., S. Ward, and P. Owende. 2012a. Environmental impacts of biogas deployment - Part I: life cycle inventory for evaluation of production process emissions to air. J. Clean. Prod. 24:168-183.

Poeschl, M., S. Ward, and P. Owende. 2012b. Environmental impacts of biogas deployment - Part II: life cycle assessment of multiple production and utilization pathways. J. Clean. Prod. 24:184-201.

Prapaspongsa, T., P. Christensen, J. H. Schmidt, and M. Thrane. 2010. LCA of comprehensive pig manure management incorporating integrated technology systems. J. Clean. Prod. 18:1413-1422.

Rajendran, K., S. Aslanzadeh, and M. J. Taherzadeh. 2012. Household biogas digesters-A review. Energies 5:2911-2942.

Rehl, T. and J. Muller. 2011. Life cycle assessment of biogas digestate processing technologies. Resour. Conserv. Recycl. 56:92-104.

Sandars, D. L., E. Audsley, C. Canete, T. R. Cumby, I. M. Scotford, and A. G. Williams. 2003. Environmental benefits of livestock manure management practices and technology by life cycle assessment. Biosyst. Eng. 84:267-281.

Schröder, J. J., D. Uenk, and G. J. Hilhorst. 2007. Long-term nitrogen fertilizer replacement value of cattle manures applied to cut grassland. Plant Soil 299:83-99.

Schulte, E. E. and B. G. Hopkins. 1996. Estimation of organic matter by weight loss-onignition. In: Soil Organic Matter: Analysis and Interpretation (Eds. F. R. Magdoff, M. A. Tabatabai, and E. A. Hanlon). SSSA Special Publication 46. Madison, WI, USA. pp. 21-31.

Smith, K. R., R. Uma, V. V. N. Kishore, K. L.V. Joshi, J. Zhang, R. A. Rasmussen, and M. A. K. Khalil. 2000. Greenhouse gases from small-scale combustion devices in developing countries, Phase IIa. Household stoves in India. United States Environmental Protection Agency. Washington, DC, USA. pp. 1-89.

SNV-VN, 2012. Domestic biogas technology training handbook. Biogas program for animal husbandry sector in Vietnam. Program supported by Netherlands Development Organisation. http://biogas.org.vn/english/An-pham.aspx Accessed 03 August, 2013.

Sogaard, H. T., S. G. Sommer, N. J. Hutchings, J. F. M. Huijsmans, D. W. Bussink, and F. Nicholson. 2002. Ammonia volatilization from field-applied animal slurry-the ALFAM model. Atmos. Environ. 36:3309-3319.

Sommer, S. G. and N. J. Hutchings. 2001. Ammonia emission from field applied manure and its reduction-invited paper. Eur. J. Agron. 15:1-15.

Sommer, S. G., J. K. Schjoerring, and O. T. Denmead. 2004. Ammonia emission from mineral fertilizers and fertilized crops. Adv. Agron. 82:557-622.

Sommer, S. G., R. R. Sherlock, and R. Z. Khan. 1996. Nitrous oxide and methane emissions from pig slurry amended soils. Soil Biol. Biochem. 28:1541-1544.

Sommer, S. G., S. O. Petersen, P. Sørensen, H. D. Poulsen, and H. B. Møller. 2007. Methane and carbon dioxide emissions and nitrogen turnover during liquid manure storage. Nutr. Cycl. Agroecosyst. 78:27-36.

ten Hoeve, M., N. J. Hutchings, G. M. Peters, M. Svanström, L. S. Jensen, and S. Bruun. 2013. Life cycle assessment of pig slurry treatment technologies for nutrient redistribution in Denmark. J. Environ. Manag. 132:60-70.

Thien Thu, C. T., P. H. Cuong, L. T. Hang, N. V. Chao, L. X. Anh, N. X. Trach, and S. G. Sommer. 2012. Manure management practices on biogas and non-biogas pig farms in developing countries - using livestock farms in Vietnam as an example. J. Clean. Prod. 27:64-71.

Thomsen, I. K., J. E. Olesen, H. B. Moller, P. Sorensen, and B. T. Christensen. 2013. Carbon dynamics and retention in soil after anaerobic digestion of dairy cattle feed and faeces. Soil Biol. Biochem. 58:82-87.

Tran, M. T., H. H. Bui, J. Luxhoi, and L. S. Jensen. 2012. Application rate and composting method affect the immediate and residual manure fertilizer value in a maize-rice-rice-maize cropping sequence on a degraded soil in northern Vietnam. Soil Sci. Plant Nutr. 58:206-23.

Tran, M. T., T. K. V. Vu, S. G. Sommer, and L. S. Jensen. 2011. Nitrogen turnover and loss during storage of slurry and composting of solid manure under typical Vietnamese farming conditions. J. Agric. Sci. 149:285-296.

Uggetti, E., I. Ferrer, E. Llorens, and J. Garcia. 2010. Sludge treatment wetlands: A review on the state of the art. Bioresour. Technol. 101:2905-2912.

UNFCCC/CCNUCC. 2012. Methodological Tool "Project and leakage emissions from anaerobic digesters" (Version 01.0.0). EB 66 Report Annex 32. CDM Executive Board.

Velthof, G. L., J. A. Nelemans, O. Oenema, and P. J. Kuikman. 2005. Gaseous nitrogen and carbon losses from pig manure derived from different diets. J. Environ. Qual. 34:698-706.

Vu, D. Q., A. D. Neergaard, D. T. Tran, T. T. H. Hoang, and T. K. V. Vu. 2014. The effect of biochar and different crop residues on greenhouse gas emissions during passive aeration composting of manure and digestate typical of small-scale livestock farms in Vietnam. Environ. Technol. http://dx.doi.org/10.1080/09593330.2014.960475

Vu, Q., T. Tran, P. Nguyen, C. Vu, V. Vu, and L. Jensen. 2012a. Effect of biogas technology on nutrient flows for small- and medium-scale pig farms in Vietnam. Nutr. Cycl. Agroecosyst. 94:1-13.

Vu, T. K. V. and X. T. Dinh. 2012b. Survey on ompact assessment of climate change on livestock production. Ministry of Agriculture and Rural Development, Hanoi, Vietnam.

Vu, T. K. V., C. C. Vu, J. M. Medoc, M. R. Flindt, and S. G. Sommer. 2012c. Management model for assessment of nitrogen flow from feed to pig manure after storage in Vietnam. Environ. Technol. 33:725-731.

Vu, T. K. V., M. T. Tran, and T. T. S. Dang. 2007. A survey of manure management on pig farms in Northern Vietnam. Livest. Sci. 112:288-297.

Vu, T. K. V., T. Prapaspongsa, H. D. Poulsen, and H. Jorgensen. 2009. Prediction of manure nitrogen and carbon output from grower-finisher pigs. Anim. Feed Sci. Technol. 151:97-110.

Vu, V. T. K., B. N. Tran, D. Q. Vu, H. C. Pham, C. C. Vu, L. S. Jensen, S. G. Sommer, and P. D. Le. 2012d. Effects of dietary 
crude protein and crude fiber levels on $\mathrm{N}$ and $\mathrm{P}$ excretion, hydrogen sulfide, ammonia and greenhouse gases emission from slurry of growing pigs between $30-60 \mathrm{~kg}$. AAAP conference, 2012, Bangkok, Thailand.

Wang C. B. and L. X. Zhang. 2012. Life cycle assessment of carbon emission from a household biogas digester: Implications for policy. Procedia Environ. Sci. 13:778-789.

Watanabe, T., T. T. Son, N. N. Hung, N. Van Truong, T. Q. Giau, K. Hayashi, and O. Ito. 2009. Measurement of ammonia volatilization from flooded paddy fields in Vietnam. Soil Sci. Plant Nutr. 55:793-799.
Webb, J., S. G. Sommer, T. Kupper, K. Groenestein, N. J. Hutchings, B. Eurich-Menden, L. Rodhe, T. Misselbrook, and B. Amon. 2012. Emissions of ammonia, nitrous oxide and methane during the management of solid manures. In: Agroecology and Strategies for Climate Change (Ed. E. Lichtfouse). Springer, Dordrecht, the Netherlands. pp. 67-107.

Yu, L., K. Yaoqiu, H. Ningsheng, W. Zhifeng, and X. Lianzhong. 2008. Popularizing household-scale biogas digesters for rural sustainable energy development and greenhouse gas mitigation. Renew. Energy 33:2027-2035.

Zhang, J., K. R. Smith, Y. Ma, S. Ye, F. Jiang, W. Qi, P. Liu, M. A. K. Khalil, R. A. Rasmussen, and S. A. Thorneloe. 2000. Greenhouse gases and other airborne pollutants from household stoves in China: a database for emission factors. Atmos. Environ. 34:4537-4549. 